\title{
Revolution und Kanon - am Beispiel von Mazzinis Goethe-Rezeption
}

\author{
Caroline Mannweiler
}

\begin{abstract}
»Poetry is the feeling of a former world and of a future. « In adopting this (slightly modified) phrase from Byron's Ravenna Journals, Mazzini in his essay Byron and Goethe (1839) tries to construct the two canoncial authors as figures of transition which in a way is an attempt to save < them. For while Mazzini is convinced of the necessity of a progressive literature that doesn't express the views of an individualistic elite only but also those of the people, he at the same time refuses the radicalness of some of his fellow campaigners who in the name of progress want to erase the past. Thus Mazzini develops an idiosyncratic notion of the canon that lets the revolutionary struggle for autonomy in the present coincide with a form of respect for generations past and to come.
\end{abstract}

Title: Revolution and canon - using the example of Mazzini's reception of Goethe

Keywords: canon; revolution; Guiseppe Mazzini (1805-1872); Johann Wolfgang Goethe (1749-1832); George Gordon Noel [Lord] Byron (1788-1824)

I stood one day in a Swiss village at the foot of the Jura, and watched the coming of a storm. Heavy black clouds, their edges purpled by the setting sun, were rapidly covering the loveliest sky in Europe, save that of Italy. Thunder growled in the distance, and gusts of biting wind were driving huge drops of rain over the thirsty plain. Looking upwards, I beheld a large Alpine falcon, now rising, now sinking, as he floated bravely in the very midst of the storm and I could almost fancy that he strove to battle with it. At every fresh peal of thunder, the noble bird bounded higher aloft, as if in answering defiance. I followed him with my eyes for a long time, until he disappeared in the east. On the ground, about fifty paces beneath me, stood a stork; perfectly tranquil and impassible in the midst of the warring elements. Twice or thrice she turned her head towards the quarter from whence the wind came, with an indescribable air of half indifferent curiosity; but at length she drew up one of her long sinewy legs, hid her head beneath her wing, and calmly composed herself to sleep. I thought of Byron and Goethe; of the stormy sky that overhung both; of the tempest-tossed existence, the life-long struggle, of the one, and the calm of the other; and of the two mighty sources of poetry exhausted and closed by them. (Mazzini 1891: 61f.; Hervorh. i.0.)

Giuseppe Mazzinis Essay Byron and Goethe, den er zunächst auf Französisch verfasste und der erstmals 1839 in englischer Übersetzung in der Zeitschrift Month- 
ly Chronicle erschien, ${ }^{1}$ beginnt mit dieser allegorisch aufgeladenen Landschaftsbeschreibung, die zum einen die poetische Qualität des Textes anzeigt, aber auch unmittelbar inhaltlich interessant ist, da Mazzini durch die Darstellung der beiden Autoren Byron und Goethe als Falke bzw. Storch ihnen eine gleichsam >natürliche< Existenz verleiht. Ihre Präsenz wird damit zu einem unwiderruflichen Faktum, das keiner Begründung bedarf und dessen Beseitigung ein gewaltsamer Eingriff vorausgehen müsste. Wie noch zu zeigen sein wird, ist dies für den weiteren Verlauf des Textes nicht ganz unwichtig. Außerdem ist in diesem Eingangsbild auch bereits der den ganzen Text durchziehende Gegensatz zwischen Byron und Goethe enthalten, der einen unversöhnten, kämpfenden Byron einem ruhigen, unbewegten, fast indifferenten Goethe gegenüberstellt. Neben dieser Gegensätzlichkeit weisen die beiden aber eine entscheidende Gemeinsamkeit auf: Sie stehen für ein Zeitalter der Poesie, das im Begriff ist, zu enden, und zwar nicht in Ruhe, sondern in einer stürmischen Zeit. Mithin entwirft Mazzini hier auch das Bild eines Übergangs oder besser: einer Situation des Umbruchs.

Dass solche Umbruchsituationen eine gewisse Affinität zu Kanonisierungsprozessen aufweisen, lässt sich Assmanns Ausführungen zum kulturellen Gedächtnis entnehmen (vgl. Assmann 2007: 123-130) und erscheint unmittelbar plausibel. Umbruchsituationen sind mit Verunsicherungen verbunden, die das Bedürfnis nach Kontinuität und identitätsstiftenden Instanzen wie dem Kanon durchaus befördern können. Und es läge angesichts der Eingangsszene von Mazzinis Text vielleicht nahe, auch Mazzini solche Kanonisierungsbemühungen zu unterstellen. Dieser Vermutung scheint allerdings der zutiefst progressive Charakter Mazzinis zu widersprechen, der sich sein ganzes Leben lang gegen herrschende Autoritäten zur Wehr gesetzt hat und der die sozial- und nationalrevolutionären Bewegungen der ersten Hälfte des 19. Jahrhunderts nicht nur unterstützte, sondern Teil von ihnen war. Der 1805 geborene Mazzini, der in fast jeder italienischen Stadt mit einer Statue repräsentiert ist, war ab den 183 oer Jahren einer der führenden Köpfe der italienischen Unabhängigkeitsbewegung und verbrachte den größten Teil seines Lebens im Exil. Wenn also Mazzini unzweifelhaft als Revolutionär gelten kann und seine Bemühungen um Goethe und Byron mithin kaum als >konservative< Kanonisierungen ${ }^{2} \mathrm{zu}$

1 | Vgl. 0.A. 1839. Der Artikel ist anonym erschienen, laut Wellesley Index aber eindeutig Mazzini zuzuweisen. Im Folgenden zitieren wir den Text in einer von Mazzini autorisierten englischen Fassung aus den Life and Writings of Joseph Mazzini (vgl. Mazzini 1891). Das französische, unveröffentlichte Original samt einer italienischen Übersetzung ist nachzulesen in Mazzini 1915. Alle diese Versionen weisen untereinander Unterschiede auf, die für die vorliegende Interpretation allerdings nicht ins Gewicht fallen.

2 | Dass die Epoche der europäischen Romantik mit ihren Kanonisierungen vor allem Shakespeares und Dantes insgesamt eine eher literarisch progressive, zumindest antiklassische Tendenz vertrat, sei hier nicht verschwiegen. Gleichwohl lässt sich Mazzini nicht restlos unter diese Bestrebungen der Romantiker subsumieren, da er mit den politischen Bewegungen des Jungen Deutschland, dessen italienisches Pendant Giovi- 
verstehen sind, welcher Natur sind sie dann? Dies soll im Folgenden kurz skizziert werden, und zwar entlang des Textes, der das zentrale Problem im Grunde gleich zu Beginn formuliert:

A reaction has now commenced; good, in so far as it reveals a desire for and promise of new life; evil, in so far as it betrays narrow views, a tendency to injustice towards departed genius, and the absence of any fixed rule or principle to guide our appreciation of the past. [...] The reaction against Goethe, in his own country especially, which was courageously and justly begun by Menzel during his lifetime, has been carried to exaggeration since his death. Certain social opinions, to which I myself belong, but which, although founded on a sacred principle, should not be allowed to interfere with the impartiality of our judgment, have weighed heavily in the balance; and many young ardent, and enthusiastic minds of our day have reiterated with Börne that Goethe is the worst of despots; the cancer of the German body. (Mazzini 1891: 63-64; Hervorh. i.0.)

Deutlich wird hier, dass Mazzini revolutionäre Tendenzen durchaus befürwortet, ihre Radikalität in der Ablehnung früherer Autoritäten jedoch zurückweist. Konkret bezieht er sich hier wohl auf das Börne zugeschriebene Diktum aus dem 14. Pariser Brief vom 30. November 1830, in dem Goethe als »Krebsschaden am deutschen Körper « (Börne 1832: 106) 3 bezeichnet wird, eine Ausdrucksweise, die Mazzini offensichtlich zuwider ist, ${ }^{4}$ wiewohl er prinzipiell den politischen Enthusiasmus eines Börne und anderer Autoren des Jungen Deutschland begrüßt. Diese Haltung Mazzinis führt zu mitunter diffizilen Argumentationen, wie der weitere Verlauf des Textes zeigt.

Gleich zu Beginn geht Mazzini darin auf einzelne Kritiker Byrons und Goethes ein, die er kaum beim Namen nennt und denen er eine gewisse Arroganz und Ignoranz angesichts der Genies Byron und Goethe vorwirft. Bei diesem Argument kann er es jedoch kaum belassen, da es ihm nicht darum zu tun ist, By-

ne Italia auf inn selbst zurückging, die Auffassung teilt, dass man sich mit literarischen ,Fortschritten` nicht mehr begnügen könne.

3 | Streng genommen zitiert Börne hier zustimmend den Ausdruck eines anonymen Wiener Gelehrten.

4 | Die abschreckende Formulierung Börnes mag auch erklären, warum Wolfgang Menzel im Vergleich als gemäßigt erscheint. Außerdem hatte Menzel in Italien einen gewissen Rezeptionsvorteil, da sein Werk Die deutsche Literatur (vgl. Menzel 1828) bereits 1831 in italienischer Übersetzung Passerinis vorlag. Gleichwohl dürfte bei allen von Mazzini begrüßten nationalen Tendenzen Menzels dessen Haltung nur schwer mit der europäischen Perspektive Mazzinis kompatibel sein, wie er sie in D'una letteratura europea 1829 aufgezeigt hat - einem Text, dem bekanntlich ein abgewandeltes GoetheZitat zur Weltliteratur voransteht (vgl. Mazzini 1906a). Zu einigen transnationalen Aspekten der italienischen Goethe-Rezeption während der Restaurationszeit vgl. Sisto 2017 sowie ausführlicher zu transnationalen Orientierungen in Mazzinis Literaturkonzept Pagliardini 2013. 
ron und Goethe als unerreichbare Vorbilder zu inthronisieren. Gerade eine solche Exklusivität wirft er vielmehr den Kritikern vor:

All judged, too many in each country still judge, the two poets, Byron and Goethe, after an absolute type of the beautiful, the true, or the false, which they had formed in their own minds; without regard to the state of social relations as they were or are; without any true conception of the destiny or mission of Poetry, or of the law by which it, and every other artistic manifestation of human life, is governed. (Mazzini 1891: 64f.)

Man könnte hier einen gewissen Widerspruch zu dem vorherigen Zitat sehen, bei dem Mazzini die Abwesenheit eines Kriteriums als Problem ansah (»the absence of any fixed rule or principle«), während hier die >verabsolutierten< Kriterien problematisch sein sollen. Tatsächlich wird dieser Widerspruch jedoch in der Folge aufgelöst, und zwar durch eine überaus integrative Vision von Tradition und Fortschritt, in der das irdische Leben von allen Errungenschaften der Vergangenheit gestärkt wird, »strengthened by all the achievements of the past«, wie es bei Mazzini lautet:

Our earthly life is one phase of the eternal aspiration of the soul towards progress, which is our Law; ascending in increasing power and purity from the finite towards the infinite; from the real towards the ideal; from that which is, towards that which is to come. In the immense storehouse of the past evolutions of life constituted by universal tradition, and in the prophetic instinct brooding in the depths of the human soul, does poetry seek inspiration. It changes with the times, for it is their expression; it is transformed with society, for - consciously or unconsciously - it sings the lay of Humanity; although, according to the individual bias or circumstances of the singer, it assumes the hues of the present, or of the future in course of elaboration, and foreseen by the inspiration of genius. It sings now a dirge and now a cradle song; it initiates or sums up. Byron and Goethe summed up. Was it a defect in them? No; it was the law of the times (ebd.: 65f.).

Mazzini verbindet hier eine historische Sichtweise, die keine überzeitlichen Kriterien kennt und somit vergangene Epochen nicht abwerten muss, mit einer progressiven, die als Kriterium ein anzunäherndes Ideal annimmt, das keine Epoche, weder die gegenwärtige noch vergangene, je erreicht hat und das auch nie vollständig erreicht werden kann. Das ist insofern wichtig, als keine goldenen Zeitalter statuiert werden, stattdessen herrscht eine implizite Vorstellung von Perfektibilität vor. Wichtig für den hier untersuchten Zusammenhang ist nun, dass die Poesie zum Bindeglied der Zeiten zu werden scheint. Sie schöpft aus dem gesamten >Warenhaus< der Vergangenheit und trägt zugleich etwas Prophetisches in sich.

Dabei besteht durchaus ein latenter Widerspruch, da die Poesie zum einen alles aufnimmt, was ihre Zeit ausmacht, und damit zeitgebunden ist, zum anderen aber bereits die Zukunft in sich tragen soll. In gewissem Sinne löst Mazzini 
dieses Dilemma durch eine ganz bestimmte religiöse ${ }^{5}$ Sichtweise, die einen Weg von der Immanenz zur Transzendenz, vom Realen zum Idealen anstrebt, wobei jedoch beide Instanzen, das Ideale und das Reale, nicht gegeneinander ausgespielt werden, sondern das Ideal eher als Horizont im Realen erscheint. Statt eines Fortschritts, der das Vergangene als >überholt< definiert, skizziert Mazzini einen Fortschritt, der Vergangenheit und Gegenwart integrieren kann.

Dennoch bleibt die Fortschrittsorientierung Mazzinis deutlich, was seinen Fall gerade interessant macht. Denn wiewohl Mazzini bemüht ist, Byron und Goethe vor gewissen gegenwärtigen Tendenzen zu >schützen<, so stellt er doch unmissverständlich klar, dass beide ein Prinzip verkörpern, das der Vergangenheit angehört, und dies ist das Prinzip der Individualität. »They were the poetical expression of what England has produced in economy, France in politics, Germany in philosophy: the last formula, the last effort, the last result, of a society founded on the principle of Individuality.« (Ebd.: 66) Hier zeigt sich Mazzini nun deutlich in seiner sozialistischen Tendenz, da er das Prinzip der individuellen Freiheit für unzureichend hält:

The political schools of the epoch had proclaimed the sole basis of civil organization to be the right to liberty and equality (liberty for all), but they had encountered social anarchy by the way. The Philosophy of the Epoch had asserted the Sovereignty of the human Ego, and had ended in the mere adoration of fact, in Hegelian immobility. The Economy of the epoch imagined it had organized free competition, while it had but organized the oppression of the weak by the strong; of labour by capital; of poverty by wealth. The Poetry of the epoch had represented individuality in its every phase; had translated in sentiment what science had theoretically demonstrated; and it had encountered the void. (Ebd.: 67; Hervorh. i.0.)

Nach Mazzini liegt die Zukunft in der Harmonisierung von Individualität und Assoziation, weshalb das Prinzip der Individualität an sein Ende gerät - ein Ende, das Byron und Goethe empfunden und ausgedrückt haben. Aufschlussreich ist nun aber, dass Mazzini sich nicht mit dieser Feststellung begnügt, sondern die beiden Poeten der >Individualität < als zugleich überholt und zukunftsfähig zu präsentieren sucht.

Im Falle Byrons gelingt dies Mazzini vor allem durch eine fast schon an Adorno gemahnende Interpretation der >Unversöhntheit< Byron'scher Charaktere. Denn diese würden sich zwar über die Welt erheben und auf eigene Stärke vertrauen: »They are grand, poetical, heroic, but solitary; they hold no communion with the world around them, unless it be to rule over it; they defy alike

5 | Dass die Berücksichtigung von Mazzinis religiösen Konzeptionen auch für ein Verständnis seines politischen Denkens wesentlich ist, zeigt lain McMenamin (vgl. 1997: 227). Interessanterweise werden die religiösen Aspekte in Mazzinis politischem Denken jedoch häufig eher als antiindividualistische, antiliberale Elemente gelesen (vgl. Levis Sullam 2010), während sie im vorliegenden Fall eher dazu dienen, einen antiliberalen bzw. sektiererischen Umgang mit Vergangenheit zu verhindern. 
the good and evil principle; they >will bend to neither.< In life and in death >they stand upon their strength « (ebd.: 70; Hervorh. i.O.). Glücklich seien sie damit aber nicht: »They all aspire to power or to happiness. The one and the other alike escape them; for they bear within them, untold, unacknowledged even to themselves, the presentiment of a life that mere liberty can never give them.« (Ebd.: 71f.) In der Unzufriedenheit der Byron'schen Helden manifestiert sich für Mazzini mithin nicht einfach eine Ablehnung der Gesellschaft, die sie umgibt, sondern ex negativo auch das Eingeständnis, dass sie durchaus der Gesellschaft bedürfen, so diese eine andere sein könnte. In ihrer Negation und Traurigkeit sieht Mazzini daher einen indirekten Wunsch nach Zukunft, Veränderung und Gesellschaft:

What can they do with the liberty so painfully won? On whom, on what, expend the exuberant vitality within them? They are alone; this is the secret of their wretchedness and impotence. They sthirst for good - Cain has said it for them all - but cannot achieve it; for they have no mission, no belief, no comprehension even of the world around them. They have never realized the conception of Humanity in the multitudes that have preceded, surround, and will follow after them; never thought on their own place between the past and future; on the continuity of labour that unites all the generations into one Whole; on the common end and aim, only to be realized by the common effort; on the spiritual post-sepulchral life even on earth of the individual, through the thoughts he transmits to his fellows (ebd.: 72f.; Hervorh. i.0.).

Die Traurigkeit der Byron'schen Helden nimmt Mazzini gleichsam zum Beweis dafür, dass das Prinzip der Freiheit des Individuums als alleiniger Maßstab nicht ausreicht ${ }^{6}$ und die Isolation des Individuums ein Irrweg ist, ein Irrweg, bei dem das Bewusstsein für gesellschaftliche Verhältnisse und das Gefühl, als Individuum Teil einer Vergangenheit und Zukunft verbindenden Arbeit zu sein, als Auswege scheinen. Interessant ist hierbei der Gedanke, dass die sozusagen synchrone Assoziation mit der Gesellschaft und eine diachrone intergenerationelle Assoziation miteinander einhergehen. Das Sich-in-eine-Tradition-Stellen folgt mithin bei Mazzini keinem elitären Gestus, sondern ist vielmehr Korrelat einer sozialen Orientierung.

Nun dürfte deutlich geworden sein, dass Byron und seine Helden diese Orientierung noch nicht wirklich vollzogen haben, weshalb sie eben nur den Keim der Zukunft tragen, nicht aber schon zu Vertretern der neuen Tendenzen geworden sind. Entscheidend ist aber in jedem Fall, dass dieser Keim in ihrem Leid deutlich wird, welches ihre isolierte Existenz als ungenügend ausweist - ein Zu-

6 | Auch dieser Gedankengang findet sich in Mazzinis politischem Denken wieder, in dem die Freiheit des Individuums, wie sie die Revolution erreichte, zwar ein erster notwendiger Schritt ist, um das Ancien Régime abzulösen, aber als dauerhafte und alleinige Orientierung nicht ausreicht - daher Mazzinis Bezug zum Volk und zur Nation, die er ihrerseits aber nicht als isoliertes Individuum begreift, sondern als Durchgangsstadium zur Humanität. 
sammenhang, den Byrons Zeitgenossen laut Mazzini vollständig übersehen haben, indem sie Byron samt seiner Figuren als heillose Egoisten interpretierten:

His intuition of the death of a form of society, they call wounded self-love; his sorrow for all, is misinterpreted as cowardly egotism. They credit not the traces of profound suffering revealed by his lineaments; they credit not the presentiment of a new life which from time to time escapes his trembling lips (ebd.: 74).

Hier wird die Verbindung von Leid und dem Wunsch nach Zukunft und Veränderung noch einmal sehr deutlich, und diese Verbindung ist es auch, die Byron und seine Helden fundamental von Goethe unterscheidet. Wie bereits in der alpinen Eingangsszene mit Goethe als dem weisen, durch nichts zu beunruhigenden Storch deutlich wurde, betont Mazzini vor allem Goethes >Ruhe $<$, die im Gegensatz zu Byrons Energie steht. Diese Akzentuierung dient aber nicht lediglich der Charakterisierung, sondern bereitet auch Mazzinis Kritik an Goethe vor. Denn wenn das Leid der Byron'schen Helden gerade ihre positive, zukunftsträchtige Qualität ist, dann muss die Ruhe Goethes konsequenterweise als >Mangel< erscheinen. Dazu passt, dass Mazzini gerade denjenigen Helden Goethes lobt, der am ehesten durch intensives Leiden auffällt, nämlich Werther: ${ }^{7}$ »After he also had uttered his cry of anguish in Werther - after having stated in all its frightful nudity, in Faust, the problem of the epoch, he thought he had done enough, and refused to occupy himself with the solution.« (Mazzini 1891: 75)

Indem Mazzini Werthers Leid als Aufschrei gegen die Verhältnisse interpretiert, lässt er Goethes Ruhe nicht lediglich als Ruhe, sondern als Indifferenz erscheinen: »Whilst Byron writhed and suffered under the sense of the wrong and evil around him, he attained the calm - I cannot say of victory - but of indifference.« (Ebd.: 75) Dass diese Indifferenz ${ }^{8}$ von Mazzini nicht gutgeheißen wird, kann kaum verwundern, steht sie doch auch für eine Indifferenz gegenüber sozialen und politischen Veränderungen, die Mazzini ein großes Anliegen sind:

Questions of life and death for the millions were agitated around him; Germany re-echoed to the war-songs of Korner; Fichte, at the close of one of his lectures, seized his musket, and joined the volunteers who were hastening (alas! what have not the kings

7 | Werther dominierte lange Zeit die Goethe-Rezeption in Italien, Mazzini legte mit einer Rezension von Nervals Faust-Übersetzung 1829 tatsächlich einen der ersten Beiträge zur Faust-Rezeption in Italien vor und beklagte darin interessanterweise den Umstand, dass Goethe nur als Autorität bekannt sei und weniger aufgrund wirklicher Kenntnis seiner Werke (vgl. Mazzini 1906b: 128). Zwar gehört es geradezu zur Definition kanonischer Werke, dass sie unabhängig von Textkenntnis bekannt sind (vgl. Heydebrand 1998: 613), trotzdem zeigt die Bemerkung, dass Mazzinis Kanonverständnis gerade nicht von unhinterfragt zu akzeptierenden Autoritäten ausgeht.

8 | Goethes ,Indifferentismus beklagt gewiss nicht nur Mazzini. Vielmehr gehört er zu den Standardvorwürfen an die Adresse Goethes von Seiten politisch bewegter Autoren, darunter Heinrich Heine. 
made of that magnificent outburst of nationality!) to fight the battles of their fatherland. The ancient soil of Germany thrilled beneath their tread; he, an artist, looked on unmoved (ebd.: 77).

Nun mag man angesichts solch nationalistischer Tendenzen Mazzinis etwas aufschrecken, festzustellen bleibt aber, dass Mazzini nationale Bewegungen auch als sozial-politisches Phänomen betrachtet, die nicht die Vorherrschaft einzelner Nationen zum Ziel haben sollen, sondern republikanische Verhältnisse in möglichst vielen Nationen. Außerdem stellt Peter Ihring treffend fest, dass Mazzini keinen fundamentalen Widerspruch zwischen nationalen und humanistischuniversalistischen Haltungen erkennt (vgl. Ihring 2005: 40), sondern die nationalen Bewegungen als notwendige Etappen ansieht, um humanistische Werte politisch wirksam durchzusetzen. ${ }^{9}$ Nun ließe sich über die Frage des Nationenbegriffs bei Mazzini gewiss trefflich streiten, und die Forschung ${ }^{10}$ hat dies auch getan, entscheidend für den gegebenen Kontext scheint aber, dass Mazzini Goethes Indifferenz gegenüber politischen Phänomenen weniger als >politische< denn als >menschliche< Schwäche kennzeichnet:

He witnessed the French Revolution in all its terrible grandeur, and saw the old world crumble beneath its strokes; and while all the best and purest spirits of Germany, who had mistaken the death-agony of the old world for the birth-throes of a new, were wringing their hands at the spectacle of dissolution; - he saw in it only the subject of

9 | Sehr aussagekräftig sind hierzu Mazzinis Erläuterungen zum Kosmopolitismus: "We are all Cosmopolitans, if by Cosmopolitanism we understand the love and brotherhood of all, and the destruction of all barriers that separate the Peoples and provide them with opposite interests. But can that be all? Is it sufficient just to proclaim these sacred truths, in order to secure their triumph over the obstacles that the league of unlawful powers present to them in Europe? Our work aims at transforming ideas into reality; we have to organize, if I may say so, not thought, but action. [...] For us, the end is humanity; the pivot, or point of support, is the country. I freely admit that for Cosmopolitans, the end is also humanity; but their pivot or point of support is man, the isolated individual." (Mazzini 2009: 58; Hervorh. i.0.)

10 | Einen aktuellen Überblick zu wichtigen Positionen geben Stefano Recchia und Nadia Urbinati (vgl. 2009), die die Bezugnahmen des italienischen Faschismus auf Mazzini dezidiert als Pervertierung seines Denkens ausweisen. Eine nuancierte Studie, die den präzisen historischen Kontext von Mazzinis Schaffen ausleuchtet, bietet Romeo (vgl. 1989). Eine Monographie, die antidemokratisches Potential in Mazzinis Denken sucht, das von den Faschisten instrumentalisiert werden konnte, hat Simon Levis Sullam 2010 vorgelegt. Der Verbindung zwischen Mazzinis Nationalbewusstsein und der faschistischen politischen Theorie geht auch Elisabeth Dickmanns Studie nach (vgl. 1982). In Baylys und Biaginis Sammelband von 2008 finden sich neben diesen vor allem inneritalienisch relevanten Beziehungen zwischen Risorgimento und Faschismus auch Beiträge zur bemerkenswert internationalen Rezeption von Mazzinis politischen Ideen. 
a farce. [...] He had neither learned to esteem men, to better them, nor even to suffer with them. (Mazzini 1891: 68)

Was Mazzini Goethe vorwirft, ist nicht, auf der falschen Seite gestanden zu haben, sondern seine fehlende Menschenliebe. Und genau diese Priorität führt Mazzini letztlich auch dazu, Goethe, trotz aller Kritik, die er an ihm im weiteren Verlauf des Textes übt, am Ende >unangetastet< zu lassen. »Let these statues stand!« (ebd.: 88), lautet der unmissverständliche Ausruf, den Mazzini seinen revolutionären Genossen zuruft. Dass damit keine Aufforderung gemeint ist, die evidente Autorität Goethes und Byrons zu feiern, sollte deutlich geworden sein. Denn sowohl Byron als auch in noch viel stärkerem Maße Goethe stehen für Tendenzen, die Mazzini als überholt ansieht, Tendenzen, die er zunächst neutral als Prinzip der Individualität kennzeichnet, dann mit stärkerer Wertung als >Egoismus<.

[T]hey arrived - Goethe, the poet of individuality in its objective life - at the egotism of indifference; Byron - the poet of individuality in its subjective life - at the egotism (I say it with regret, but it, too, is egotism) of despair: a double sentence upon the epoch which it was their mission to represent and to close! (Ebd.: 84)

Das in Egoismus endende Prinzip der Individualität kennzeichnet Mazzini eindeutig als nicht zukunftsträchtig. Es hatte seine Zeit, und Mazzini erwähnt an anderer Stelle auch lobend die emanzipatorischen Einflüsse des Individualitätsprinzips, jedoch sieht er es an sein Ende gekommen. Um den Fortschritt der Menschheit zu befördern, ist für Mazzini künftig die soziale Dimension entscheidend.

Die Schlussfolgerung, die er daraus zieht, ist jedoch eine, die man nicht zwingend erwarten würde:

It would be idle to speak of social art at all, or of the comprehension of humanity, if we could not raise altars to the new gods, without overthrowing the old. Those only should dare to utter the sacred name of progress, whose souls possess intelligence enough to comprehend the past, and whose hearts possess sufficient poetic religion to reverence its greatness. The temple of the true believer is not the chapel of a sect; it is a vast Pantheon, in which the glorious images of Goethe and Byron will hold their honored place, long after Goetheism and Byronism shall have ceased to be. (Ebd.: 88f.; Hervorh. i.0.)

Fortschritt mit der Zerstörung von Vergangenheit zu untermauern, erscheint Mazzini widersinnig. Wer für den Fortschritt der Menschheit kämpft, so ließe sich aus seinem Text folgern, kann nicht Teile dieser Menschheit ausmerzen wollen - sei es auch nur in Form der ideellen Zerstörung oder der Eradikation von Spuren der Vergangenheit.

Interessant ist in diesem Zusammenhang, dass die Art des Umgangs mit vergangener >Größeく, die Mazzini bei einigen Zeitgenossen beobachtet, ein fast 
schon physisches Unbehagen auslöst, das unabhängig von möglichen Motiven eine Akzeptanz dieses Verhaltens unmöglich zu machen scheint:

I feel the necessity of protesting earnestly against the reaction set on foot by certain thinkers against the mighty-souled, which serves as a cloak for the caviling spirit of mediocrity. There is something hard, repulsive, and ungrateful, in the destructive instinct which so often forgets what has been done by the great men who preceded us, to demand of them merely an account of what more might have been done. (Ebd.: 87)

In diesen Passagen nähert sich Mazzini in gewisser Weise einem >Great man<Diskurs an, unterscheidet sich aber doch von diesem, insofern die Kritik nicht durch den Verweis auf die Qualität der >great men < unterbunden wird, sondern durch den Verweis darauf, dass eine solche radikale und undankbar vorgetragene Kritik sich im Grunde selbst disqualifiziert. Letztlich erkennt Mazzini in ihr das Symptom eigener Unsicherheit, die einen gelassenen und selbstbewussten Umgang mit Vergangenheit unmöglich macht. Nur wer sich seiner eigenen Ideale sicher ist, kann die unterschiedlichen Ideale der Vergangenheit bewerten und als >gewesene< akzeptieren, ohne von ihrer Unterschiedlichkeit bedroht $\mathrm{zu}$ sein: »It is not by deposing Goethe or Byron, that we shall destroy either sceptical or anarchical indifference amongst us. It is by becoming believers and organizers ourselves. [...] Let these statues stand. The noble monuments of feudal times create no desire to return to the days of serfdom.«(Ebd.: 88) Statt einer politisch motivierten Vergangenheitspolitik skizziert Mazzini einen Umgang mit vergangenen Epochen und ihrer Kunst, den man als liberal bezeichnen könnte, so sich die Konnotation von Indifferenz, die diesen Begriff begleitet, vermeiden ließe. Denn Indifferenz, das wurde ja an seiner Position gegenüber Goethe deutlich, gehört zu Mazzinis >ärgsten< Feinden. In der Tat ist Mazzinis Haltung schwer auf den Begriff zu bringen. Dass er einer Form von Humanismus verpflichtet bleibt, lässt sich aber wohl in jedem Fall behaupten (und dürfte ein Hauptgrund dafür gewesen sein, dass Mazzini trotz ähnlicher Analysen von Marx nie wirklich ernst genommen wurde). ${ }^{11}$ Dieser Humanismus nötigt ihn gleichsam, die Verurteilung vergangener Epochen und Persönlichkeiten zu überwinden, hin zu einer Vision, in der Humanität stets ein allumfassender, gerade nicht sektiererischer Begriff ist. Entscheidend für den Zusammenhang von Revolution und Kanon ist nun, dass diese Humanität bei Mazzini eine diachrone Dimension umfasst, worunter man nicht die Vorstellung einer selbstverständlichen Kontinuität oder eines speziellen verpflichtenden Erbes verstehen sollte, sondern vielmehr eine Form von Verbundenheit, die sich in der Gegenwart als Bewusstsein von vergangenen und zukünftigen Zeiten äußert: »Poetry is the feeling of a former world and [of a] future.« (Mazzini 1891: 90) Diese Definition, die Mazzini in leicht abgewandelter Form aus Byrons Ravenna Journal entnimmt (vgl. Byron 1978: 37), formuliert diese wesentliche Bedeutung eines Gefühls für >Zeitlichkeit< im Sin-

11 | Die erstaunliche Nähe einiger Schriften Mazzinis zu Überlegungen von Marx zeigt Mastellone (vgl. 2003). 
ne eines die eigene Person berührenden Bewusstseins für vergangene Zeiten, die es nicht einfach zu imitieren gilt, sondern die eine Dimension jenseits des eigenen Horizonts eröffnen - und damit auch einen Zukunftshorizont andeuten. ${ }^{12}$ Vor diesem Hintergrund kann Mazzini dann sogar so weit gehen, Byron zu einem Gefährten der Partei des Fortschritts zu erklären:

The following passage from his journal is the very abstract of the law governing the efforts of the true party of progress at the present day: "Onwards! it is now the time to act; and what signifies self, if a single spark of that which would be worthy of the past can be bequeathed unquenchably to the future?" (Mazzini 1891: 91)

Nun ist das Zukunftsorientierte, Aktive, bei Byron gewiss stärker ausgeprägt als bei Goethe, man denke nur an sein Engagement an der Seite der griechischen Unabhängigkeitskämpfer, das Mazzini natürlich emphatisch begrüßt. Die Definition der Poesie als verbindendes Element, das sich im Horizont von Vergangenheit und Zukunft konstituiert, gilt allerdings selbstverständlich auch für Goethe, weshalb auch seine >Statue $<$ nicht zerstört werden sollte.

Zusammenfassend ließe sich also behaupten, dass Mazzini in Byron and Goethe ein Konzept von Kanonizität entwirft, das weder durch unhinterfragbare Autorität noch durch eine spezifische, eventuell auch politisch motivierte Vergangenheitskonstruktion geprägt ist, sondern vielmehr durch den Wunsch, Übergänge zwischen Zeiten zu schaffen - Übergänge, die eine Alternative zu >radikalen< Lösungen darstellen, sofern mit diesen die Vorstellung einhergeht, alle >Wurzeln< entfernen zu müssen, bevor etwas Neues entstehen kann. Nicht umsonst schließt Mazzini seinen Text mit folgendem Bild:

Certain travellers of the eleventh century relate that they saw at Teneriffe a prodigiously lofty tree, which, from its immense extent of foliage, collected all the vapors of the atmosphere; to discharge them, when its branches were shaken, in a shower of pure and refreshing water. Genius is like this tree, and the mission of criticism should be to shake the branches. At the present day it more resembles a savage striving to hew down the noble tree to the roots. (Ebd.: 94)

12 Einen nicht unähnlichen Gedanken scheint Friedrich Schlegel gehabt zu haben: "Durch die Künstler wird die Menschheit ein Individuum, indem sie Vorwelt und Nachwelt in der Gegenwart verknüpfen." (Schlegel 1967: 262) Der Zukunftsbezug ist bei Mazzini gewiss stärker ausgeprägt, was angesichts seiner politischen Ideale kaum überraschen kann. Dass Mazzinis Interpretation Byrons als progressivem, auf der Seite der Völker kämpfenden Dichter nicht zuletzt Mazzinis eigenen Bedürfnissen entgegenkam, betont Crisafulli (vgl. 2012: 392). 


\section{LITERATUR}

Assmann, Jan (2007): Das kulturelle Gedächtnis. Schrift, Erinnerung und politische Identität in frühen Hochkulturen. München.

Bayly, Christopher Allan/Biagini, Eugenio Federico (Hg.; 2008): Giuseppe Mazzini and the Globalization of Democratic Nationalism, 1830-1920. Oxford.

Börne, Ludwig (1832): Briefe aus Paris. 1830-1831. Bd. 1. Hamburg.

Byron, George Gordon Noel (1978): Ravenna Journals [1821]. In: Ders.: Byron's Letters and Journals. Hg. v. Leslie A. Marchand. Bd. 8. London, S. 11-50.

Crisafulli, Lilla Maria (2012): Poetry as Thought and Action: Mazzini's Reflections on Byron. In: History of European Ideas 38, H. 3, S. 387-398.

Dickmann, Elisabeth (1982): Die Rezeption Giuseppe Mazzinis im italienischen Faschismus. Frankfurt a.M.

Heydebrand, Renate von (1998): Kanon Macht Kultur - Versuch einer Zusammenfassung. In: Dies. (Hg.): Kanon Macht Kultur: theoretische, historische und soziale Aspekte ästhetischer Kanonbildung. Stuttgart/ Weimar, S. 612-625.

Inring, Peter (2005): Einführung in die italienische Literatur des 19. Jahrhunderts. Berlin.

Levis Sullam, Simon (2010): L'apostolo a brandelli. L'eredità di Mazzini tra Risorgimento e fascismo. Bari/Rom.

Mastellone, Salvo (2003): Mazzini and Marx: Thoughts Upon Democracy in Europe. Westport/London

Mazzini, Giuseppe (1891): Byron and Goethe [1839]. In: Ders.: Life and Writings of Joseph Mazzini. Bd. 6. London, S. 61-97.

Ders. (1906a): D'una letteratura europea [1829]. In: Ders.: Scritti editi e inediti. Bd. 1. Imola, S. 177-222.

Ders. (1906b): Faust, Tragédie de Goethe. Nouvelle traduction complète en prose et en vers par Gérard [de Nerval], Paris, Dondey-Duprey etc., 1828 [1829]. In: Ders.: Scritti editi e inediti. Bd. 1. Imola, S. 127-151.

Ders. (1915): Byron et Goethe [1840]. In: Ders.: Scritti editi e inediti. Bd. 21. Imola S. $187-241$.

Ders. (2009): Nationality and Cosmopolitanism [1847]. In: Ders.: A Cosmopolitanism of Nations. Giuseppe Mazzini's Writings on Democracy, Nation Building, and International Relations. Hg. v. Stefano Recchia/Nadia Urbinati. Princeton, S. 57-62.

McMenamin, lain (1997): ,Self-choosing، and right-acting، in the nationalism of Giuseppe Mazzini. In: History of European Ideas 23, H. 5-6, S. 221-334.

Menzel, Wolfgang (1828): Die deutsche Literatur. Zwei Theile. Stuttgart.

0.A. [Giuseppe Mazzini] (1839): Byron and Göthe. In: The Monthly Chronicle. A national journal of politics, literature, science and art 4, S. 242-254.

Pagliardini, Angelo (2013): Mappe interculturali della letteratura italiana nel Risorgimento: Ugo Foscolo, Vincenzo Cuoco, Giuseppe Mazzini, Cristina Trivulzio di Belgiojoso, Giuseppe Gioachino Belli. Frankfurt a.M. u.a. 
Recchia, Stefano/ Urbinati, Nadia (2009): Introduction. In: Giuseppe Mazzini: A Cosmopolitanism of Nations. Giuseppe Mazzini's Writings on Democracy, Nation Building, and International Relations. Hg. v. Stefano Recchia u. Nadia Urbinati. Princeton, S. 1-30.

Romeo, Rosario (1989): Mazzinis Programm und sein revolutionärer Einfluss in Europa. In: Adolf M. Birke/Günther Heydemann (Hg.): Die Herausforderung des europäischen Staatensystems. Nationale Ideologie und staatliches Interesse zwischen Restauration und Imperialismus. Göttingen /Zürich, S. 15-30.

Schlegel, Friedrich (1967): Ideen [1800]. In: Ders.: Kritische Friedrich Schlegel Ausgabe. Hg. v. Ernst Behler. Bd. 2. Paderborn, S. 256-272.

Sisto, Michele (2017): Goethe in Weimar-Paris-Mailand. Exilrevolutionäre, Zeitschriften, Verlage und die Produktion eines italienischen Faust (1814-1837). In: Christophe Charle/Hans-Jürgen Lüsebrink/York-Gothart Mix (Hg.): Transkulturalität nationaler Räume in Europa (18. bis 19. Jahrhundert). Übersetzungen, Kulturtransfer und Vermittlungsinstanzen. Bonn, S. 267-286. 
